\title{
PENTINGNYA PENDIDIKAN KEWARGANEGARAAN JUGA PENERAPAN DAN RELEVANSI DALAM KEHIDUPAN DI ERA TEKNOLOGI GENERASI MILENIAL
}

\author{
Elza Amalia Salsya Bani dan Dinie Anggraeni Dewi \\ Universitas Pendidikan Indonesia Bandung, Indonesia \\ Email: elzaamalia@upi.edu dan anggraenidewidhinie@upi.edu
}

\begin{abstract}
The purpose of this study is to get an overview related to the application of relevance in life in the era of technology millennials. The method used in this study is qualitative method with descriptive research. The research instrument used uses interview guidelines, notes in the field. Data analysis techniques ranging from data collection, data reduction, to conclusion drawing. The result of this study is that the author states that millennials are a generation that is currently very vulnerable when not getting moral and religious education, even good and strong citizenship. This is because today's young generation is very vulnerable in believing information that is not yet clear validity, or commonly known as hoaxes, when the child is unable to distinguish between the original news and the fake one. If this is the case continuously, then Indonesia in the future will be prone to be divided, because its successors are easy to be pitted against if they cannot distinguish between the right and the not.
\end{abstract}

Keywords: overview; education; generation

\begin{abstract}
Abstrak
Tujuan dari penelitian ini yaitu agar mendapatkan gambaran berkaitan dengan penerapan relevansi dalam kehidupan di era teknologi generasi milenial. Latar belakang dari penelitian ini adalah agar Pendidikan kewarganegaraan tidak terjadi ketertinggalan zaman dalam penerapan pengajarannya sudah seharusnya menggunakan sarana dan fasilitas. Metode kualitatif dengan penelitian deskriptif digunakan saat penulis melakukan penelitian ini. Instrument penelitian yang digunakan menggunakan pedoman wawancara, catatan di lapangan. Teknik yang digunakan saat menganalisis sebuah data pertama data tersebut dikumpulkan, kemudian melakukan reduksi data, hingga dapat diambil kesimpulan. Hasil dari penelitian ini adalah penulis menyatakan bahwa generasi milenial merupakan generasi yang saat ini sedang sangat rentan bila tidak mendapatkan pendidikan moral dan juga agama, bahkan kewarganegaraan yang baik dan kuat. Hal ini disebabkan generasi muda saat ini sangat rawan dalam mempercayai informasi yang belum jelas keabsahannya, atau yang biasa dikenal dengan nama hoax, bila anak tersebut tidak mampu untuk membedakan antara berita yang asli dengan yang palsu. Jika seperti ini terus menerus, maka Indonesia di masa depan akan rawan untuk terpecah belah, karena penerusnya mudah untuk diadu domba bila tidak dapat membedakan yang benar dan yang tidak.
\end{abstract}

Kata Kunci: gambaran; pendidikan; generasi

$\begin{array}{ll}\text { How to cite: } & \text { Elza Amalia Salsya Bani dan Dinie Anggraeni Dewi (2021) Pentingnya Pendidikan } \\ & \text { Kewarganegaraan Juga Penerapan dan Relevansi dalam Kehidupan Di Era Teknologi Generasi } \\ & \text { Milenial. Syntax Idea 3(4). http://dx.doi.org/10.36418/syntax-idea.1167 } \\ \text { E-ISSN: } & \text { 2684-883X } \\ \text { Published by: } & \text { Ridwan Institute }\end{array}$




\section{Pendahuluan}

Menjadi warga negara yang baik memerlukan dasar dan penanaman pengertian mengenai kewarganegaraan itu. Untuk mewujudkan masyarakat bernegara yang baik, tentunya dibutuhkan penanaman nilai dan pemahaman mengenai peraturan juga hukum yang berlaku di negara tersebut pula (Fauzi et al., 2013). Oleh karena itu, Indonesia mengadakan mata pelajaran Pendidikan Kewarganegaraan untuk masyarakatnya, terlebih untuk siswa yang masih menduduki bangku sekolah. Salah satu pembelajaran yang harus dapat diterapkan dilingkungan masyarakat adalah Pendidikan Kewarganegaraan, selayaknya yang telah tertulis di dalam Undang-Undang No. 20 Tahun 2003 (Manurung, 2019) berkaitan dengan sistem pendidikan nasional. Di dalam Undang-Undang ini, dinyatakan bahwa setiap jenis, jenjang pendidikan, dan setiap jalur pendidikan yang ada diwajibkan memuat tiga pelajaran utama, yaitu pendidikan di bidang bahasa, pendidikan yang mengajarkan tentang agama, dan juga Pendidikan yang sangat mengutamakan nilai kewarganegaraan.

Pendidikan Kewarganegaraan sendiri resmi menjadi pelajaran wajib di Indonesia sejak tahun 1968, dimana akhirnya Kementerian Pendidikan dan Kebudayaan Indonesia mengubah nama pendidikan kewarganegaraan menjadi Pendidikan Moral Pancasila atau PMP. Namun, karena perubahan era menjadi masa reformasi, nam (Lestariningsih, 2011). Pendidikan Moral Pancasila itu kembali diubah menjadi pendidikan kewarganegaraan, karena dianggap nama pendidikan kewarganegaraan terlihat menunjukkan maksud dari adanya mata pelajaran ini, yaitu agar warga negara Indonesia khususnya generasi penerus bangsa memiliki jiwa nasionalisme dan patriotisme yang tinggi. Pendidikan kewarganegaraan ini sendiri memiliki beberapa tujuan selain tujuan umum yaitu memperbaiki moral bangsa dan membangun karakter yang baik untuk generasi muda (Ubaedillah, 2016).

Pendidikan kewarganegaraan ini bukan hanya sebatas mata pelajaran biasa yang terdapat di sekolah, namun selalu ada di lingkungan masyarakat, terutama di dalam aspek sosial. Pendidikan kewarganegaraan sudah melebur dengan kehidupan sehari-hari masyarakat dan menjadi kebiasaan yang dilakukan oleh warga negara Indonesia. Pembelajaran selama ini berlangsung secara verbalistic atau dijelaskan dengan katakata, dan memiliki orientasi semata-mata hanya kepada penguasaan isi per-bab dari mata pelajaran pendidikan kewarganegaraan dibandingkan dengan praktiknya di kehidupan nyata, sedangkan pendidikan kewarganegaraan merupakan pendidikan yang harus diperhatikan praktiknya juga di dunia nyata.

Generasi milenial merupakan generasi yang tumbuh di era serba teknologi seperti di zaman ini. Sudah banyak kemajuan baik dari segi transportasi, alat telekomunikasi, bahkan pendidikan. Generasi milenial bisa dibilang sudah tumbuh di zaman modern dimana banyak kemudahan yang diberikan, salah satunya adalah media sosial (Faiza \& Firda, 2018). Menurut Larry dan Richard E. Potter, adanya media sosial ini membuat perubahan yang sangat drastis kepada generasi milenial, terutama di dalam kehidupan bermasyarakat mereka. Kehadiran media sosial ini membawa perubahan terhadap kepercayaan (beliefs), nilai atau values, dan sikap atau attitudes terhadap generasi 
milenial. Dalam hal ini, media sosial itu sendiri mampu membuat generasi milenial berubah perilakunya sesuai dengan iman dan juga kepercayaan yang mereka anut. Selain itu, media sosial juga dapat menggeser nilai-nilai sosial di dalam masyarakat, yang mana nilai sosial tersebut terkadang tergantikan dengan nilai yang buruk, sehingga tentunya merusak moral generasi muda. Lalu, media sosial ini juga dapat mengubah cara masyarakat terutama generasi milenial untuk berkomunikasi.(W et al., 2020)

Dari contoh kecil berupa media sosial ini, telah terbukti bahwa ini merupakan urgensi terhadap moral dari generasi muda, karena terlalu cepatnya perkembangan zaman dan teknologi, sehingga terlalu sulit untuk mengatur moral dan perbuatan generasi masa kini. Seperti yang sudah dijabarkan, generasi milenial dapat terpengaruh oleh media sosial dimana mereka melakukan hal yang menurut kepercayaan mereka, hal itu tidak salah. Padahal, bisa saja hal yang mereka lakukan merupakan kesalahan yang melanggar norma yang ada di masyarakat. Hanya saja, karena telah terjadi pergeseran nilai yang signifikan di masyarakat karena perkembangan teknologi dan informasi yang melesat dengan cepat. Jika hal ini tidak dikendalikan, maka ke depannya negara Indonesia akan memiliki penerus yang tidak baik, yang kemungkinan terburuknya dapat membuat Indonesia menjadi terbelakang dan mengancam keberlangsungan bangsa. Oleh karena itu, perlu diadakannya pengendalian berupa penanaman nilai-nilai kenegaraan yang baik berupa Pendidikan Kewarganegaraan yang telah diterapkan menjadi mata pelajaran wajib di sekolah-sekolah berbagai jenjang, bahkan juga universitas agar moral dari generasi muda sendiri tidak tergerus oleh zaman dan teknologi.

\section{Metode Penelitian}

Penelitian ini menggunakan pendekatan bersifat kualitatif dan penelitian deskriptif. Pendekatan yang bersifat kualitatif merupakan jenis pendekatan yang digunakan untuk memecahkaan sebuah masalah sehingga mampu mendeskripsikan keadaan berdasarkan fakta-fakta yang terlihat jelas dan nyata. Jenis penelitian yang digunakan adalah penelitian deskriptif mempunyai tujuan agar memperoleh pengetahuan tentang situasi bagaiamana, berapa, serta seberapa jauh status masalah yang sedang diteliti. Teknik yang digunakan untuk melakukan penelitian ini yaitu pengumpulan data dengan metode observasi langsung.(Arikunto, 2013)

Observasi dilakukan untuk melihat bagaimana penerapan PKN dalam kehidupan sehari-hari apakah masih dapat dilaksanakan atau tidak. Observasi yang dilaksanakan juga bermaksud untuk melakukan penelitian secara langsung sehingga penulis mampu untuk mendapatkan informasi dengan jelas dan nyata. Mulai dari mengamati, melakukan wawancara dengan 3 orang, hingga pengambilan dokumentasi peneliti lakukan secara langsung.

\section{Hasil dan Pembahasan}




\section{A. Penerapan dan Relevansi pendidikan kewarganegaraan dalam kehidupan generasi milenial di era teknologi.}

Di Indonesia dan juga di negara-negara Asia, pendidikan kewarganegaraan yang ada lebih menekankan kepada karakter perseorangan atau individu, atau biasa dikenal dengan aspek moral individu, perspektif internasional atau pandangan terhadap negara lain selain negaranya, dan juga identitas nasional. Di era globalisasi dan teknologi seperti saat ini, diperlukan adanya penguatan terhadap pendidikan karakter terlebih pendidikan kewarganegaraan, agar jati diri bangsa Indonesia tidak hilang tergerus arus globalisasi. Pendidikan kewarganegaraan atau biasa yang disebut dengan civic education merupakan sebuah mata pelajaran yang bertujuan untuk membentuk karakteristik masyarakat bangsa Indonesia, yakni sebagai upaya untuk sadar dalam "nation and character building". (Winataputra, U dan Budimansyah, 2012). Tertulis jelas bahwa pendidikan kewarganegaraan ini bertujuan untuk membentuk kepribadian masyarakat Indonesia menjadi lebih baik dan sesuai dengan apa yang tertulis di dalam Pancasila dan juga Undang-Undang Dasar 1945, juga menciptakan manusia Indonesia sebagai warga negara yang memiliki wawasan kenegaraan mengenai tanah airnya sendiri, menanamkan adanya rasa nasionalisme atau yang dikenal dengan cinta tanah air, dan juga meningkatkan kebanggaan menjadi warga negara Indonesia di dalam diri para generasi muda. Fungsi dari pendidikan kewarganegaraan ini sendiri merupakan sarana atau fasilitas untuk membangun masyarakat negara yang terampil, cerdas, dan juga memiliki kepribadian yang selalu setia dengan bangsa dan juga negara Indonesia dengan melibatkan individu tersebut dalam hal untuk berpikir atau berperilaku, sesuai dengan yang tertera di dalam Pancasila dan Undang-Undang Dasar 1945 (UUD 1945).(Milenial, n.d.)

Pendidikan Kewarganegaraan jika ditilik aspek historis atau sejarahnya, maka akan diketahui bahwa Pendidikan Kewarganegaraan ini sangat erat kaitannya dengan istilah "civic" atau yang dalam bahasa Yunani merupakan penduduk sipil atau penduduk setempat dari sebuah negara kota atau yang biasa disebut polis. Warga sipil ini melakukan praktik demokrasi langsung di dalam negara kota tersebut. Istilah ini sangat popular di negara-negara Barat, yang menganggap bahwa istilah ini tidak hanya seputar government, hak, maupun kewajiban dari sebuah negara, melainkan community civics, economy civics, dan juga vocational civics.(Ujang Jamaludin et al., 2017) Di Indonesia, pengenalan terhadap istilah civics ini dimulai pada tahun 1961, dimana istilah ini digunakan ketika membahas sejarah nasional, negara proklamasi, UUD NRI Tahun 1945, pidato kenegaraan dan juga Pancasila menjadi dasar pembinaan terhadap persatuan dan kesatuan bangsa. Akhirnya, pada tahun 1968, pelajaran ini menjadi diketahui bernama Pendidikan Kewarganegaraan. Pada tahun 1975, pelajaran ini berubah menjadi istilah Pendidikan Moral Pancasila, yang pada tahun 1994 kembali disebut dengan istilah Pendidikan Kewarganegaraan atau PKn. Akhirnya, di tahun 2004, Pendidikan Kewarganegaraan menetapkan namanya dan isi dari pelajaran ini adalah Pancasila, persatuan, dan kesatuan Indonesia. Pendidikan Kewarganegaraan sendiri merupakan mata pelajaran yang memiliki fokus atau tujuan 
terhadap pengembangan karakter warga negara yang dapat lebih mengetahui dan mampu untuk melaksanakan hak juga kewajibannya sebagai warga negara Indonesia yang terampil, tegas, cinta tanah air, juga memiliki karakteristik yang baik, seperti yang tertulis di dalam Pancasila dan Undang-Undang Dasar Negara Republik Indonesia tahun 1945. Hakikat dari Pendidikan Kewarganegaraan ini adalah cara atau upaya yang sadar dan juga terencana negara Indonesia untuk mencerdaskan kehidupan bangsa dan negaranya. Bagi warga negara Indonesia, dengan menumbuhkembangkan jati diri dan juga moral atau karakter bangsa sebagai landasan atau dasar untuk melaksanakan hak dan kewajiban dalam melakukan kegiatan bela negara. Hal ini dilakukan demi keberlangsungan hidup dan juga kejayaan bangsa dan negara untuk kedepannya, juga warga negara Indonesia.(Izma \& Kesuma, 2019)

Menurut (Kumalasari et al., 2016) secara umum, Pendidikan kewarganegaraan memiliki beberapa tujuan pengembangan (Jamaludin, $2017 \mathrm{hlm} \mathrm{5),} \mathrm{yaitu:}$

a. Nilai-nilai mengenai cinta tanah air Indonesia.

b. Warga negara yang memiliki kesadaran dalam kehidupannya berbangsa dan bernegara.

c. Masyarakat yang berkeyakinan mengenai Pancasila sebagai ideologi negara Indonesia.

d. Nilai demokrasi, Hak Asasi Manusia (HAM), dan juga keberlangsungan terhadap lingkungan hidup dikenal dan juga terdapat di dalam Pendidikan Kewarganegaraan ini.

e. Kerelaan seseorang untuk berkorban demi masyarakat, bangsa, dan Negara.

f. Melatih kemampuan awal bela Negara.

Selain itu, berdasarkan Keputusan Dirjen Dikti No. 267/Dikti/2000, tujuan dari Pendidikan Kewarganegaraan terkhusus kepada mahasiswa sebagai garda terdepan masyarakat dan generasi muda mencakup hal-hal berikut, yaitu:

a. Tujuan Umum

Tujuan secara umum dari Pendidikan Kewarganegaraan merupakan pemberian wawasan dan juga kemampuan praktik mendasar terhadap mahasiswa mengenai kaitan dan juga interaksi antar setiap masyarakat di suatu negara dengan negaranya, juga Pendidikan Pendahuluan Bela Negara (PPBN) agar masyarakat di suatu negara dapat diandalkan oleh bangsa dan juga negaranya dengan baik. Selain itu, tujuan umum dari pemberian Pendidikan Kewarganegaraan ini untuk meningkatkan pengetahuan mahasiswa tentang arti pendidikan bela negara, yaitu hal ini sebagai salah satu dari kewajiban warga negara atau masyarakat di suatu negara yang sesuai dengan Pasal 30 UUD 1945. Oleh karena itu, kedua mata kuliah ini menjadi mata kuliah wajib untuk diikuti dan diambil oleh seluruh mahasiswa, yang pada tahun 2000 disebut sebagai Mata Kuliah Pembinaan Kepribadian atau MKPK.

b. Tujuan khusus

Selain tujuan umum, terdapat pula tujuan khusus dari Pendidikan Kewarganegaraan, yaitu: 
1) Supaya mahasiswa dapat dengan baik memahami, juga melaksanakan hak dan kewajiban sebagaimana mestinya sebagai warga negara yang berpendidikan dan bertanggungjawab dengan santun, jujur, juga demokratis yang ikhlas.

2) Supaya mahasiswa dapat memahami dan juga menguasai mengenai berbagai permasalahan yang terdapat di kehidupan bermasyarakat, berbangsa, dan juga bernegara. Selain itu, dapat memberikan solusi dan melakukan tindakan preventif dengan menggunakan pemikiran yang kritis juga bertanggung jawab dengan dilandaskan Pancasila, Wawasan Nusantara, dan Ketahanan Nasional.

3) Supaya mahasiswa dapat memiliki perilaku yang sesuai dengan apa yang disebut dengan nilai dari perjuangan, pengorbanan, cinta tanah air. Nilai pengorbanan mencakup perilaku rela berkorban untuk nusa dan bangsa.

Pendidikan Kewarganegaraan berkaitan dengan sangat erat kepada Pancasila, karena warga negara harus melakukan atau mempraktikkan butir nilai dalam Pancasila di kehidupan sehari-hari dan dapat menjadi masyarakat yang baik apabila menerapkan nilai-nilai Pancasila tersebut. Terdapat lima perwujudan dari segi normatif terhadap Pancasila di dalam kehidupan sehari-hari, yaitu sebagai berikut:

a. Nilai Ketuhanan

Nilai Ketuhanan ini meliputi perkembangan mengenai religiusitas yang menaikkan harkat dan juga martabat kemanusiaan, lalu menciptakan keadilan di masyarakat atau keadilan sosial dengan tetap menghargai keberagaman iman, dengan tetap melandaskan melalui semangat solidaritas seluruh warga negara Indonesia atau semangat persatuan nasional.

b. Nilai Kemanusiaan

Nilai kemanusiaan ini meliputi dan berkaitan dengan Hak Asasi Manusia (HAM). Setiap hak pasti memiliki kewajiban, begitupun dengan penegakannya dari hak-hak yang ada. Penegakan terhadap Hak Asasi Manusia ini tidak pernah terlepas dari Kewajiban Asasi Manusia atau KAM. KAM dilandasi oleh sikap menghargai sebagai sesama makhluk Tuhan. Bentuk apresiasi dan menghargai terhadap sesama makhluk ciptaan Tuhan ini dilakukan melalui dikembangkannya solidaritas atau persatuan sosial, kultural atau kebudayaan, dan juga ekonomi dalam lingkup nasional Indonesia.

c. Nilai Persatuan

Nilai persatuan di dalam perwujudannya berarti setiap warga negara Indonesia harus melindungi segenap tumpah darah dan sesama rakyat Indonesia, meskipun memiliki latar belakang yang berbeda. Indonesia memiliki tingkat kemajemukan yang tinggi, sehingga latar belakang yang berbeda-beda baik dalam segi historis, religius, sosiologis, dan kulturalnya. Perlindungan terhadap sesama rakyat Indonesia ini berpegang kepada prinsip demokrasi kerakyatan, kemanusiaan, dan keadilan sosial yang ada di Indonesia.

d. Nilai Kerakyatan

Dalam nilai kerakyatan, perkembangan demokrasi untuk berbagai aspek kehidupan tetap dilandasi atau berdasarkan kepada nasionalitas, religiusitas, dan 
juga nilai kemanusiaan yang ada, demi terwujudnya keadilan sosial yang seadiladilnya bagi seluruh rakyat Indonesia.

e. Nilai Keadilan Sosial

Perwujudan nilai keadilan sosial ini berupa pengembangan sistem perekonomian negara yang tetap berpijak atau berdasar dengan kepentingan negara Indonesia, juga melindungi ekonomi atau harta negara dengan tetap memperhatikan keberagaman sistem perekonomian kerakyatan yang berdasar kepada pluralitas terhadap identitas kebudayaan dan sistem perekonomian lokal.

Penerapan mengenai pendidikan Kewarganegaraan ini sendiri dapat ditemui di dalam kehidupan sehari-hari. Pendidikan Kewarganegaraan selalu mengajarkan agar generasi penerus bangsa yakni generasi milenial belajar untuk bertoleransi, karena Pendidikan Kewarganegaraan sendiri mengajarkan perbedaan yang ada di kehidupan bermasyarakat seperti suku, agama, ras, kepercayaan, dan lainnya. Pembelajaran Pendidikan Kewarganegaraan ini pada dasarnya merupakan penerapan dalam proses interaksi antara peserta didik dengan lingkungan sekitarnya, dan diharapkan karena sudah mempelajari Pendidikan Kewarganegaraan, perilaku seseorang dapat menjadi lebih baik, dan salah satu dari perilaku tersebut merupakan toleransi. Melihat bahwa Indonesia merupakan negara dengan kemajemukan atau tingkat keberagaman yang tinggi, maka seluruh masyarakat terkhusus generasi milenial harus menjunjung tinggi sikap toleransi untuk meminimalisir terjadinya konflik dan memastikan bahwa seluruh warga negara dapat hidup dengan aman, nyaman, dan damai. Sudah banyak pula generasi milenial yang mengadakan kampanye anti rasisme, juga kesadaran mereka untuk tidak rasis kepada sesama anak bangsa. Bahkan, beberapa universitas mengadakan dengan terang-terangan organisasi atau kegiatan anti-rasisme, dan ini sudah sesuai dengan salah satu hal yang diajarkan di dalam pendidikan kewarganegaraan, yaitu saling menghormati dan tidak membeda-bedakan dengan SARA.

Pendidikan Kewarganegaraan memiliki peranan penting untuk memperkenalkan pelajaran Pendidikan Kewarganegaraan yang selalu dikaitkan dengan nilai karakter atau ciri khas dari sebuah bangsa. Generasi muda harus memiliki beberapa karakter atau sifat berikut yang dapat menjadi patokan dalam pengembangan karakter berbasis Pendidikan Kewarganegaraan:

1. Religius

Religius merupakan sikap patuh terhadap ajaran dari agama atau kepercayaan yang dianut oleh seseorang, namun tetap menghormati perbedaan agama dan kepercayaan lain. Generasi muda yang memiliki karakter religius diharapkan sudah dapat menjadi dasar atau landasan dalam nilai, moral, dan juga etika bertindak di dalam kehidupan bermasyarakat.

2. Jujur

Jujur merupakan perbuatan dengan dasar percobaan atau upaya untuk menjadikan sendiri sebagai individu yang dapat dipercaya baik dari perkataan, perbuatan, dan juga pekerjaan atau hasil dari tugas yang diberikan. Dengan menjadi orang yang memiliki sifat jujur, maka minim kemungkinan untuk 
seseorang menjadi objek dari kesalahpahaman dan tuduh menuduh, atau penyebab dari terjadinya kebencian karena merasa telah dibohongi.

3. Tanggung jawab

Sikap bertanggung jawab merupakan sikap seseorang yang berprinsip dan dapat diandalkan, dan dengan adanya perbuatan ini di setiap tindakan atau pekerjaan yang generasi muda lakukan, maka dapat menjadi bukti bahwa individu tersebut memiliki kelayakan untuk mengemban dan juga diberikan mandat, berani dan mampu menanggung akibat dan resiko apapun dari tindakannya.

4. Toleransi

Toleransi secara sederhana merupakan sikap untuk menghargai setiap perbedaan. Toleransi merupakan perbuatan seseorang yang selalu menghargai atau menghormati terdapatnya perbedaan di lingkungan sosialnya. Indonesia merupakan negara dengan kemajemukan tinggi, sehingga semua orang dituntut untuk meningkatkan rasa toleransi guna untuk meminimalisir konflik. Dengan adanya toleransi, maka setiap individu akan mudah untuk saling berbaur tanpa adanya pembeda-bedaan.

5. Disiplin

Perbuatan disiplin merupakan bentuk dari perbuatan seseorang yang menaati setiap tata tertib yang berlaku baik di tempat umum maupun tidak. Hal ini menunjukkan bahwa generasi muda dapat menghargai setiap aturan, waktu, dan juga hukum yang telah disepakati untuk ada di suatu tempat atau wilayah.

6. Kerja Keras

Perilaku kerja keras dapat menunjukkan bahwa seseorang merupakan individu tersebut adalah individu dengan karakter yang pantas untuk menjadi teman dalam bekerja sama, karena seseorang dengan karakter pekerja keras akan selalu berusaha dengan keras di dalam setiap tindakan, dengan mandiri, optimis, dan juga tegas.

7. Kreatif

Dengan pikiran yang kreatif dan kritis, seseorang dapat menunjukkan bahwa ia merupakan pribadi yang cerdas. Seseorang yang cerdas akan terhindar dari halhal yang bersifat plagiarisme atau menjiplak sesuatu yang telah diciptakan orang lain dan berujung menghasilkan sesuatu yang inovatif juga dapat digunakan untuk kepentingan orang banyak.

8. Demokratis

Demokratis merupakan cara seseorang untuk berpikir, bersikap ataupun bertindak, dimana seseorang tersebut menilai bahwa hak dan kewajiban dirinya dengan orang lain sama. Orang dengan pikiran yang demokratis biasanya lebih terorganisir karena orang tersebut dapat memilah antara mana yang lebih penting dan harus dikerjakan duluan (prioritas) dengan mana yang dapat dikerjakan setelah pekerjaan utama selesai.

9. Semangat Kebangsasan dan Cinta Tanah Air

Seseorang yang memiliki semangat kebangsaan dan juga rasa cinta terhadap tanah aitnya sangat diperlukan. Karena tanpa adanya kesadaran dari warga negara 
dan juga rasa nasionalisme atau cinta tanah air, sebuah bangsa yang memiliki karakter tidak dapat terwujud karena ciri khas atau sifat bangsa tersebut merupakan suatu perwujudan dari warga negara yang mendiami.

10. Peduli Terhadap Lingkungan dan Sosial

Generasi muda yang mempunyai karakter atau sifat yang peduli terhadap lingkungan di sekitar dan juga sosialnya akan lebih disegani. Karena jika seseorang terlihat mempedulikan lingkungan dan sosialnya, maka seseorang tersebut dapat disegani dan lebih dicintai oleh orang-orang di lingkungan sosial tempatnya berada.

Untuk menciptakan generasi muda yang bermoral dan memiliki karakter selayaknya yang menjadi tujuan Pendidikan Kearganegaraan, maka Pendidikan Kewarganegaraan dapat diberikan ke dalam karakter generasi muda melalui tiga tahapan, yaitu:

1. Pembelajaran

Dalam kegiatan pembelajaran Pendidikan Kewarganegaraan, selain menjadikan seorang individu menguasai dan mencapai kompetensi atau standar kemampuan yang ditargetkan, lembaga pendidikan atau pihak yang memberikan pendidikan kewarganegaraan kepada suswa dapat merancang untuk menjadikan generasi muda untuk mengenal apa yang sedang dipelajarinya, menyadari pentingnya pendidikan kewarganegaraan, menginternalisasikan atau meresapi ke dalam diri nilai-nilai yang dipelajari di dalam pendidikan kewarganegaraan dan menjadikannya sebagai kebiasaan baik yang dilakukan setiap hari.

2. Kegiatan co-kurikuler atau kegiatan ekstrakurikuler

Kegiatan ekstrakurikuler adalah kegiatan tambahan atau tidak wajib di lembaga pendidikan yang biasanya ada di sekolah dan lembaga perguruan tinggi, dimana kegiatan ini menyediakan fasilitas untuk individu mengembangkan kemampuannya sesuai dengan bakat dan minatnya diluar dari akademis. Kegiatan ini memerlukan dukungan dengan pedoman atau tata cara sebelum melaksanakan, adanya pengembangan mengenai kapasitas SDM atau tenaga kerja dalam rangka untuk menjadi dukungan pelaksanaan pendidikan 18 karakter yang telah dicanangkan. Selain itu, terdapat pula proses atau revitalisasi kegiatan ekstrakurikuler ini mengarah kepada pengembangan karakternya.

3. Alternatif pengembangan dan juga adanya pembinaan karakter di sekolah sebagai penerapan terhadap budaya yang sebenarnya.

4. Aktivitas sehari-hari seorang individu di rumah maupun di masyarakat.(Mulyasa, 2004)

Penerapan pendidikan kewarganegaraan oleh generasi milenial ini tidak harus sesuatu yang besar dan berskala nasional, namun kesadaran dalam hal-hal kecil juga berarti sudah melakukan apa yang diajarkan di dalam pendidikan kewarganegaraan. Di dalam pendidikan kewarganegaraan, diajarkan bahwa seluruh waarga negara harus taat dengan hukum dan seluruh aturan yang berlaku di Indonesia. Aturan yang berlaku bukan hanya pasal-pasal berat seperti tindakan kriminal, terorisme, dan yang lainnya, namun juga hal-hal kecil di dalam kehidupan sehari-hari. Sebagai contoh, 
patuh dengan lalu lintas. Mematuhi rambu-rambu yang terpasang di jalanan, juga mematuhi saat sedang berada di lampu merah. Ketika berada di jalan, mematuhi semua yang berlaku di jalan dan tidak melanggar, juga tidak enggan untuk mengingatkan pengendara lain atau anggota masyarakat yang melanggar tata tertib lalu lintas.

Selain peraturan seperti yang ada di lalu lintas, generasi milenial Indonesia sebagai generasi yang tumbuh di lingkungan masyarakat yang berbudaya juga harus turut serta dalam meneruskan adat dan tradisi yang ada di negara Indonesia. Sesuai dengan nilai di dalam Pancasila yaitu keadilan sosial, kita sebagai generasi penerus bangsa juga harus menjaga toleransi dan keadilan terhadap sesama anak bangsa. Juga harus menjaga kelestarian dari budaya yang selama ini ada di Indonesia. Partisipasi dalam Pemilu atau demonstrasi juga merupakan bentuk penerapan pendidikan kewarganegaraan, karena jika seseorang berpartisipasi dalam pemilu dan tidak memilih untuk golput atau menjadi golongan yang tidak memilih, seseorang tersebut berarti telah mengetahui penting dan berharganya suara mereka untuk keberlangsungan bangsa Indonesia ke depannya. Partisipasi di dalam demonstrasi juga termasuk ke dalam tindakan yang menunjukkan kepedulian terhadap masa depan negara, juga bentuk perwujudan dari kebebasan mengemukakan pendapat di depan umum yang dicantumkan di dalam Pasal 28 Undang-Undang Dasar 1945. Selain itu, generasi milenial di masa kini seringkali lebih menyukai kebudayaan negara lain dibandingkan kebudayaan Indonesia. Setelah mempelajari Pendidikan Kewarganegaraan, diharapkan generasi muda Indonesia dapat tidak lebih membanggakan bangsa lain namun merendahkan Indonesia sebagai negaranya, terlebih merendahkan kebudayaan Indonesia. Generasi muda sebagai calon penerus bangsa harus dapat memperkenalkan kebudayaan Indonesia ke negara lain dengan bangga. Terdapat pula hal-hal sederhana yang mencerminkan penerapan Pendidikan Kewarganegaraan di dalam kehidupan generasi muda. Generasi muda dapat menghormati hasil musyawarah dan memutuskan segala sesuatu dengan menggunakan musyawarah mufakat. Musyawarah mufakat adalah karakteristik dari bangsa Indonesia sejak zaman dahulu dalam menyelesaikan masalah atau mencari solusi untuk suatu pembahasan. Dalam pelaksanaan musyawarah, tidak diperbolehkan untuk memaksakan kehendak kepada orang lain dan harus menghormati apapun hasil musyawarah, baik pendapat kita diterima atau tidak diterima di dalam musyawarah tersebut.

Pada penelitian sebelumnya (Maksum Hafidh, 2016) mengatakan bahwa menerapkan pendidikan kewarganegaraan di Indonesia saat ini meskipun ada banyak kendala, itu harus diperbaiki, dan berat. Pendidikan kewarganegaraan di sekolah masih sangat membutuhkan peningkatan. Pendidikan dasar dan menengah hanya mempunyai sekolah bermutu dalam jumlah terbatas, tidak peduli itu dikelola oleh pemerintah maupun swasta, jadi tidak cukup untuk mendidik lulusan yang memadai hanya cukup untuk melaksanakan pendidikan kewarganegaraan yang komprehensif dan berkualitas tinggi. Ini bukan tidak mungkin untuk memiliki banyak siswa yang memenuhi syarat, tetapi kebanyakan siswa sebagai calon kader atau warga negara, 
kualitasnya belum bisa dijamin mengisi dan melaksanakan berbagai pekerjaan dan pekerjaan yang ada dalam suatu pekerjaan Masyarakat di abad ke-21.

Relevansi pendidikan kewarganegaraan ini sangat penting karena pendidikan kewarganegaraan ini berkaitan erat dengan Pancasila sebagai dasar negara dan ideologi yang berlaku di Indonesia. Pancasila sebagai dasar negara berlaku menjadi identitas diri masyarakat Indonesia sebagai sebuah bangga. Oleh karena itu, generasi milenial harus mampu menerapkan nilai-nilai kehidupan yang ada di dalam Pancasila, guna agar tidak tenggelam ke dalam arus budaya asing. Di Indonesia, globalisasi bergerak dengan cepat sekali sehingga terjadi beberapa nilai lokal yang tergeser dengan nilai-nilai global. Oleh karenanya, pendidikan kewarganegaraan yang diberikan untuk generasi muda di segala jenjang pendidikan masih sangat relevan, karena pendidikan kewarganegaraan ini digunakan untuk menjadi benteng bagi para penerus Indonesia ini untuk ke depannya. Hal ini disebabkan karena butuh antisipasi untuk permasalahan kenegaraan di Indonesia nanti, juga mengantisipasi masuknya budaya negara lain yang sifatnya destruktif dan dapat menggeser nilainilai budaya lokal.

\section{Kesimpulan}

Negara Indonesia dengan ideologinya yang berupa Pancasila mewajibkan tiga mata pelajaran, yaitu mata pelajaran pendidikan bahasa, pendidikan agama, dan pendidikan kewarganegaraan. Hal ini disebabkan Indonesia ingin meningkatkan karakter dan memperbaiki kualitas pemudanya yang merupakan generasi milenial, dimana generasi milenial ini akan menjadi penerus bangsa dalam beberapa tahun ke depan. Oleh sebab itu, perlu diberikan penanaman pendidikan karakter yang baik untuk penerus bangsa ini, agar ke depannya, eksistensi Indonesia dengan kebudayaan yang ada di dalamnya tetap terjaga.

Pendidikan kewarganegaraan dalam penerapan pengajarannya sudah seharusnya menggunakan sarana dan fasilitas yang mengikuti perkembangan zaman, sehingga generasi milenial tidak merasa bosan. Karena generasi milenial ini merupakan generasi yang tumbuh di tengah kemajuan teknologi, sehingga pendidikan kewarganegaraan dapat diberikan dengan cara yang menyesuaikan dengan fasilitas yang dimiliki oleh siswa. Pendidikan kewarganegaraan tidak hanya berupa materi, namun juga berupa penerapan nyata ke dalam kehidupan sebagai anak bangsa. Adanya pendidikan kewarganegaraan sebagai mata pembelajaran wajib di semua tingkat ini menyebabkan sudah banyak anak bangsa yang menyadari pentingnya perbuatan yang sesuai dengan nilai yang terdapat di Pancasila, juga pentingnya menerapkan nilai-nilai tersebut dalam kehidupan. Generasi milenial juga sudah menyadari pentingnya menggunakan hak suara mereka dalam kemajuan demokrasi negara Indonesia. Sudah banyak yang aktif dalam berpartisipasi dalam pemerintahan baik secara langsung maupun tidak langsung. Mereka sudah menunjukkan kepedulian mereka terhadap kemajuan bangsa dan negara, sehingga dapat disimpulkan bahwa pendidikan kewarganegaraan yang diberikan berhasil. Selain itu, pendidikan kewarganegaraan juga relevan dengan keadaan masa kini, karena generasi milenial yang sangat dekat dengan teknologi dan globalisasi 
sangat rawan bila tidak dibatasi dengan pendidikan agama dan juga kewarganegaraan yang kuat. Mereka gampang tergeser keyakinannya, karena generasi milenial ini dikenal melakukan sesuatu sesuai dengan apa yang diyakini mereka benar dan tepat untuk dilakukan, padahal bisa saja hal tersebut merupakan hal yang salah di mata masyarakat. Pendidikan kewarganegaraan ini juga diberikan untuk mempersiapkan setiap calon pemimpin bangsa Indonesia di masa depan nanti agar tidak ada keretakan pemahaman para elit bangsa yang akhirnya dapat mendorong keretakan maupun disintegrasi bangsa, karena Indonesia sendiri sudah mulai tergeser kekhasannya di segala aspek karena adanya globalisasi.

Oleh sebab itu, pendidikan kewarganegaraan ini masih sangat relevan untuk diadakan, bahkan untuk pendidikan tinggi sederajat universitas sekalipun.(Nurmalisa et al., 2020) Peranan mahasiswa adalah untuk menguatkan penanaman nilai Pancasila yang ada di dalam kehidupan sehari-hari. Untuk mewujudkan cita-cita bangsa Indonesia, generasi muda sangat berperan dan diharapkan dapat menciptakan karakteristik atau ciri khas yang baik bagi Indonesia. Masa depan bangsa Indonesia sangat ditentukan oleh generasi muda yang sudah terpelajar atau terdidik, terlatih, dan memahami nilai-nilai di dalam Pancasila. Terlebih, generasi milenial merupakan generasi yang banyak mendapatkan berbagai pengetahuan, baik dari segi teori atau teoritis maupun dari segi praktik atau praktis di sekolah dan juga perguruan tinggi. Hal ini semakin membuktikan bahwa pemahaman mengenai pendidikan kewarganegaraan dan juga penerapannya sangat dibutuhkan, karena generasi muda merupakan satusatunya generasi yang memungkinkan untuk merubah pandangan orang maupun negara lain terhadap negara Indonesia, dan menjadi tumpuan dari generasi yang dahulu dalam pengembangan suatu bangsa dengan ide maupun gagasan dan inovasi yang berilmu, wawasan yang luas, dan juga berdasarkan nilai dan norma-norma sosial yang berlaku di masyarakat. 
Elza Amalia Salsya Bani dan Dinie Anggraeni Dewi

\section{BIBLIOGRAFI}

Arikunto, S. (2013). Prosedur Penelitian Suatu Pendekatan Praktek. PT. Rineka Cipta.Google Scholar

Faiza, A., \& Firda, S. J. (2018). Arus metamorfosa milenial. Penerbit Ernest. Google Scholar

Fauzi, F. Y., Arianto, I., \& Solihatin, E. (2013). Peran guru Pendidikan Pancasila dan Kewarganegaraan dalam upaya pembentukan karakter peserta didik. Jurnal PPKn UNJ Online, 1(2), 1-15. Google Scholar

Izma, T., \& Kesuma, V. Y. (2019). Peran Pendidikan Kewarganegaraan Dalam Membangun Karakter Bangsa. Wahana Didaktika: Jurnal Ilmu Kependidikan, 17(1), 84. Google Scholar

Jamaludin, U. dkk. (2017). Pendidikan Kewarganegaraan. 10. Google Scholar

Jamaludin, Ujang, Damanhuri, Setiawan, D., \& Raharjo. (2017). Kewarganegaraan Untuk Perguruan Tinggi. Google Scholar

Kumalasari, R. C., Martini, M., \& Purwantisari, S. (2016). Hubungan Sanitasi Dengan Status Bakteriologi (Status Koliform dan Keberadaan Salmonella sp) Pada Jajanan Di Sekolah Dasar Wilayah Kecamatan Tembalang, Semarang. Jurnal Kesehatan Masyarakat (e-Journal), 4(3), 98-107. Google Scholar

Lestariningsih, A. D. (2011). Gerwani: kisah tapol wanita di Kamp Plantungan. PT Gramedia Pustaka Utama. Google Scholar

Maksum; Hafidh, A.;Faisal. (2016). Peran Pendidikan Kewarganegaraan Di Era Glbalisasi Dalam Menumbuhkan Semangat Nasionalisme. Pendidikan, 5(2), 1-11. Google Scholar

Manurung, L. H. (2019). Efektivitas Pembelajaran Pkn Terhadap Pendidikan Karakter Siswa Dalam Mempersiapkan Generasi Millennial. Google Scholar

Milenial, B. G. (2010). Revitalisasi Pendidikan Kewarganegaraan Bagi GENERASI MILENIAL Humaidi Dosen Prodi PAI STAI Al Falah Banjarbaru. 140-146. Google Scholar

Mulyasa, E. (2004). "kurikulum Berbasis Kompetensi: Konsep, Karakteristik, dan Implementasi”. PT. Remaja Rosdakarya. Google Scholar

Nurmalisa, Y., Mentari, A., \& Rohman, R. (2020). Peranan Pembelajaran Pendidikan Kewarganegaraan Dalam Membangun Civic Conscience. Bhineka Tunggal Ika: Kajian Teori Dan Praktik Pendidikan PKn, 7(1), 34-46. Google Scholar

Ubaedillah, A. (2016). Pendidikan Kewarganegaraan Pancasila, Demokrasi dan 
Elza Amalia Salsya Bani dan Dinie Anggraeni Dewi

Pencegahan Korupsi. Prenada Media. Google Scholar

W, R. W. A., Poluakan, M. V., Dikayuana, D., Wibowo, H., \& Raharjo, S. T. (2020). Potret Generasi Milenial Pada Era Revolusi Industri 4.0. Focus : Jurnal Pekerjaan Sosial, 2(2), 187. Google Scholar

Winataputra, U dan Budimansyah, D. (2012). Pendidikan Kewarganegaraan dalam Perspektif Internasional: Konteks, Teori dan Profil Pembelajaran. Widya Aksara Press. Google Scholar

\section{Copyright holder :}

Elza Amalia Salsya Bani dan Dinie Anggraeni Dewi (2021)

First publication right :

Journal Syntax Idea

This article is licensed under:

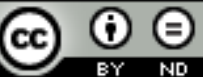

